\title{
AKUNTANSI SUMBER DAYA MANUSIA
}

\author{
Oleh: \\ Princilvanno Andreas Naukoko \\ Fakultas Ekonomi dan Bisnis \\ Universitas Sam Ratulangi Manado \\ email:v4naukoko@yahoo.com
}

\begin{abstract}
Nowadays, accounting has developed more widely than just a study that provides financial information of organization. One of the development that still debated is about to put human resources as an asset. The ideas for put human resources as an asset are known as Human Resources Accounting (HRA). This research is for give a definition, recognition, measurement, and the constraints of HRA by using research literatures method. The results of this research shows that, the main problem in using human resources as an asset is about, how the organization measure the human resources and reveal it in financial report. As a conclusion from this research is HRA still needs further research, especially about to determine which kind of organization that is suitable to apply HRA in financial report.
\end{abstract}

Keywords: Human Resource Accounting (HRA), definition, recognition, measurement, and constraints.

\section{PENDAHULUAN}

Akuntansi adalah bahasa atau alat komunikasi bisnis yang dapat memberikan informasi tentang kondisi keuangan (ekonomi) berupa posisi keuangan yang terutang dalam jumlah kekayaan, utang dan modal suatu bisnis dan hasil usahanya pada suatu waktu atau periode tertentu (Harahap, 2007). Perkembangan ilmu akuntansi sendiri tidak hanya sebatas memberikan informasi kondisi ekonomi saja, tetapi mengacu kepada informasi-informasi yang diperlukan oleh manajemen dalam pengambilan keputusan. Perkembangan disiplin ilmu akuntansi yang begitu cepat sudah merambah kepada akuntansi manajemen, di samping akuntansi keuangan sendiri.

Disiplin akuntansi manajemen sendiri telah mengembangkan ilmu Akuntansi Sumber Daya Manusia (ASDM). Hal ini didorong akan meningkatnya kesadaran akan asset yang paling berharga dalam perusahaan adalah sumber daya manusia (SDM) khususnya intellectual capital. Perkiraan kas, aktiva tetap, aktiva berwujud dan tidak berwujud lainnya berada dalam kendali manusia. Tanpa manusia, sumber daya perusahaan itu tidak akan bias menghasilkan laba atau menambah nilainya sendiri. Manusialah yang mengelola suatu perusahaan dan manusialah yang menciptakan nilai tambah itu. Selain manusia aktiva yang dimiliki oleh perusahaan adalah aktiva pasif yang tidak bias berbuat apa-apa tanpa intervensi kebijakan manusia (Harahap, 2007).

Informasi yang menyajikan nilai dari SDM yang dimiliki oleh perusahaan masih belum bisa dilihat dalam laporan keuangan akuntansi konvensional. Kalaupun ada dalam laporan keuangan hanyalah menunjukkan besarnya biaya gaji atau biaya pelatihan, pendidikan. Semua biaya yang dikeluarkan untuk SDM diasumsikan sebagai biaya operasional saja (revenue expenditure, expense approach) bukan sebagai pengeluaran modal (capital expenditure). (Harahap, 2007)

Dengan semakin berkembangnya tuntutan kualitas informasi akuntansi yang dihasilkan, terutama bagi perusahaan yang sangat mengandalkan Intellectual Capital, 
muncullah perkembangan baru dari Akuntansi yaitu Akuntansi Sumber Daya Manusia (ASDM). Riset ini bertujuan untuk memberikan definisi, pengakuan, pengukuran dan kendala dalam mengaplikasikan ASDM berdasarkan pada beberapa riset dan tinjauan pustaka.

\section{PEMBAHASAN \\ Definisi ASDM}

Perkembangan baru di bidang akuntansi khususnya ASDM atau Human Resource Accounting (HRA) telah menjadi bahan pembicaraan sejak tahun 1960. ASDM pada saat itu lahir sebagai akibat dari semakin berkembangnya teori akuntansi itu sendiri, hanya saja perkembangannya masih memandang perspektif sumber daya manusia serta perhatian terhadap sumber daya manusia sebagai komponen dan goodwill bagi perusahaan.

Rensis Likert, Eric G. Flamholtz dan beberapa peneliti lainnya telah mengembangkan beberapa riset akademik dari model dan teori mengenai ASDM sejak tahun 1967. Tujuannya adalah untuk menyajikan sumber daya manusia adalah untuk mengindentifikasi perubahan nilai sumber daya manusia dengan demikian dapat diketahui sumber daya manusia di perusahaan itu mengalami peningkatan atau penurunan nilai pada periode tertentu.

Flamhotz dalam Tunggal (1995), menyebutkan bahwa "human resource accounting means accounting for people as an organizational resource". Artinya, ASDM berarti akuntansi untuk manusia sebagai suatu sumber daya organisasi. Hal ini berarti, ASDM merupakan suatu perkembangan dari ilmu akuntansi yang khusus untuk mengukur manusia sebagai salah satu sumber daya yang dimiliki oleh organisasi.

The Committee on Human Resources Accouting dan AAA (Belkaoui, 1995) mendefinisikan ASDM sebagai suatu proses mengidentifikasikan dan mengukur data tentang sumber daya manusia dan menyampaikan informasi ini kepada mereka yang berkepentingan. Belkaoui (1995) mendefinisikan ASDM sebagai suatu proses mengidentifikasi, mengukur data tentang SDM dan mengkomunikasikan informasi ini kepada pihak yang berkepentingan. Definisi Belkaoui berarti ASDM bertujuan untuk mengidentifikasikan nilai SDM, mengukur biaya dan nilai manusia yang dikontribusikan kepada perusahaan, dan mengkaji pengaruh pemahaman informasi ini dan dampaknya pada perilaku manusia. (Harahap, 2007).

Pandangan lainnya mengenai ASDM dikemukakan oleh Brummed, dimana Brummed melihat ASDM sebagai suatu konsep yang meliputi sumber daya manusia sebagai aktiva, penentuan biaya yang diinvestasikan dan hubungannya dengan biaya-biaya hasil pakai, estimasi dan menyediakan ketelitian ekonomi tentang nilai sumber daya manusia dalam organisasi (Brummet, 1995). Sedangkan menurut Lako (1995): ASDM adalah sebuah proses pengidentifikasi dan pengukuran data tentang sumber daya manusia dan pengomunikasiannya atas informasi-informasi yang termasuk di dalamnya kepada pihak-pihak yang berkepentingan.

ASDM dapat diartikan sebagai suatu proses pengukuran dan pelaporan biaya nilai manusia sebagai salah satu sumber daya organisasi dan pelaporan kepada pihak yang berkepentingan. Dengan demikian pada proses ASDM terdapat unsur pengukuran, pelaporan, data tentang manusia dan organisasi. Data tentang manusia dalam hal ini berupa biaya-biaya untuk seleksi, penerimaan, pelatihan dan pengembangan kemampuan pegawai serta informasi lainnya yang berupa tingkat pendidikan, pengalaman, usia, keadaan kesehatan dan lain sebagainya. (Ayu dan Didied).

Berdasarkan pada beberapa definisi ASDM yang telah dikemukakan sebelumnya, ASDM dapat disimpulkan sebagai suatu bidang ilmu akuntansi yang berfokus pada manusia sebagai sumber daya organisasi. Sebagai sumber daya organisasi, SDM harus dapat diukur dan dilaporkan. Pengukuran yang digunakan dalam ASDM bukanlah berdasarkan pada biaya operasional saja, tetapi sebagai biaya atau pengeluaran modal. Oleh karena itu, SDM dalam suatu perusahaan harus dapat dinilai sejak proses penyeleksian, perekrutan, pelatihan dan pengembangan kemampuan pegawai agar dapat diketahui perkembangan dari nilai SDM sebagai asset dalam suatu organisasi dalam suatu periode tertentu. 
SDM sangat berbeda dengan aktiva perusahaan yang lainnya. Perbedaannya jelas terdapat pada kemampuan fisik dan kemampuan untuk menghasilkan laba keuangan bagi perusahaan. Secara skematis Flamholtz dalam Harahap (2007) mengemukakan ruang lingkup ASDM sebagai berikut.

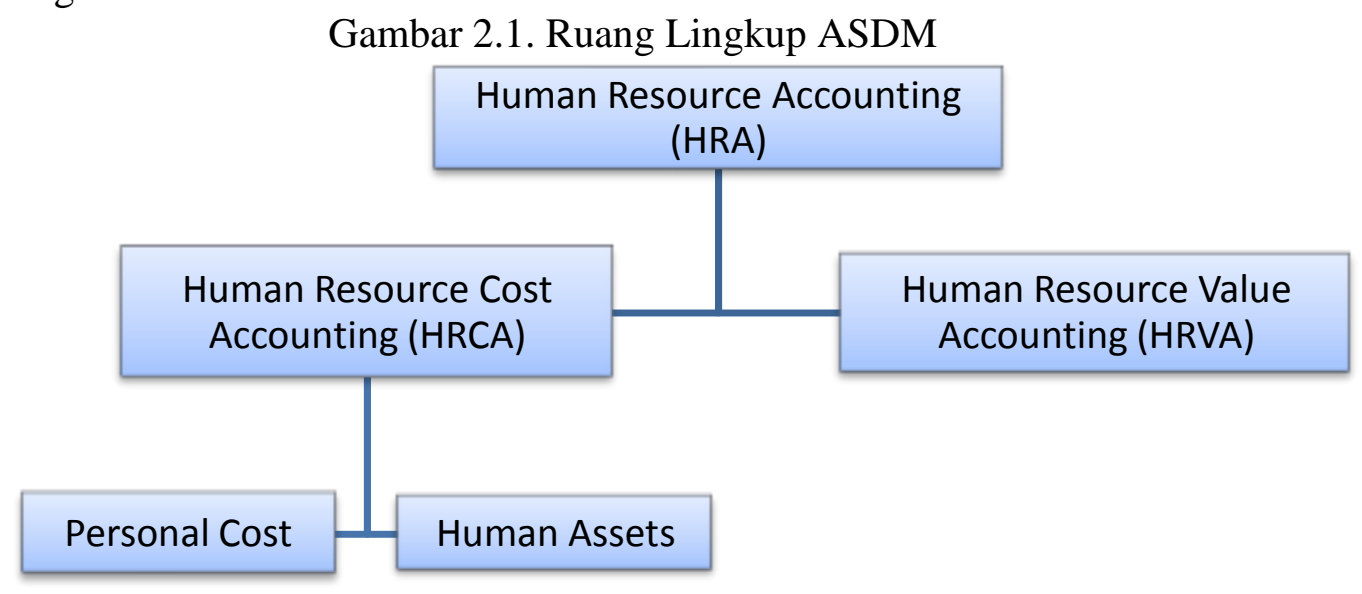

Sumber : Tunggal dalam Ayu dan Didied

1. Human Resource Cost Accounting (HRCA) adalah pengukuran dan pelaporan biaya yang timbul untuk pencarian, pengembangan dan penggantian tenaga sebagai sumberdaya organisasi. Dalam hal ini terdapat dua jenis cost berkenaan dengan HRCA ini, yaitu:

1. Personal Cost Accounting adalah biaya yang berhubungan dengan fungsi proses manajeman personalia dalam pencarian dan pengembangan sumberdaya manusia.

2. Human Assets Accounting mencakup Cost manusia itu sendiri dimasukkan sebagai human resource dari suatu perusahaan.

2. Human Resource Value Accounting (HRVA). Pengertian value di sini adalah present value of future service. Sedangkan HRVA adalah: present worth of future service that people are expected to provide.

\section{Pengakuan}

ASDM telah disepakati bersama di kalangan akuntan sebagai bagian dari asset perusahaan yang sangat besar kontribusinya dalam memberikan mafaat ekonomis masa depan ke perusahaan. Upaya memasukkan sumberdaya manusia sebagai asset dalam neraca terganjal karena harus memenuhi kriteria pengakuan sebagai asset perusahaan.

IASB Framework dalam Mirza, dan Holt (2011) mendefinisikan assets sebagai " $a$ resource controlled by the entity as a result of past events and from which future economic benefits are expected to flow to the entity". Artinya, asset adalah sumber daya yang dikendalikan oleh entitas sebagai hasil dari peristiwa masa lalu dan diharapkan akan memberikan pengembalian ekonomis kepada entitas.

Dilihat dari definisi asset diatas, maka SDM dapat dikategorikan sebagai sumber daya yang dimiliki oleh perusahaan sebagai akibat dari kegiatan masa lalu (perekrutan, pelatihan dan pengembangan kemampuan SDM dalam perusahaan) yang diharapkan akan memberikan pengembalian kepada perusahaan. Kelemahannya, dalam akuntansi konvensional yang dirancang untuk menilai semua asset yang dimiliki oleh perusahaan, tidak terdapatnya pengukuran dan penilaian SDM dengan alasan asset manusia bukanlah asset yang bertahan lama dan sangat berpindah sehingga sulit untuk melakukan proses evaluasi dengan menggunakan metode secara formal. (Nicoline, 2010).

Dalam praktiknya, perusahaan akan mengeluarkan biaya tertentu dalam proses untuk mendapatkan SDM yang memiliki standar dan kualitas yang diinginkan oleh perusahaan. Biaya - biaya yang di maksud adalah menyangkut hal yang dikeluarkan perusahaan untuk 
biaya untuk seleksi, penerimaan, pelatihan dan pengembangan kemampuan SDM dalam perusahaan. Oleh karena itu, untuk menerapkan ASDM maka harus ada metode atau pendekatan untuk pengukuran dari SDM yang dimiliki oleh perusahaan.

\section{Pengukuran}

Sampai saat ini pengukuran secara kuantitatif untuk menilai SDM dengan sifat dasar akuntansi dimana pengukuran yang dipakai dalam akuntansi adalah dalam bentuk ukuran moneter atau uang (monetary unit) jika diakui sebagai aset perusahaan, masih menjadi suatu masalah. General Accepted Accounting Standard (GAAP) sendiri belum sepakat untuk memasukkan sumber daya ini sebagai suatu element dalam Balanced Sheet.

Dalam pengukuran ASDM terdapat dua kelompok besar model penentuan biaya SDM. Dua model pengukuran tersebut terdiri dari, Human Resource Cost Model dan Human Resource Value Model. (Harahap, 2007).

1. Human Resource Cost Model (HRCM).

Model pengukuran ASDM ini didasarkan pada biaya-biaya yang dikeluarkan untuk pencarian, pengembangan dan penggantian tenaga sebagai sumber daya organisasi. Dalam HRCM terdapat tiga model pengukuran sebagai berikut.

a. The Historical Cost Model. Model yang diperkenalkan oleh Flamholtz untuk pengukuran dalam ASDM, yang mana mengidentifikasikan biaya awal ASDM kedalam dua kelompok biaya sebagai berikut.

1) Acquisition Cost, yaitu semua pengorbanan yang harus dikeluarkan untuk mendapatkan pejabat baru. Biaya langsung seperti biaya rekrutrmen, biaya seleksi, hiring dan penempatan. Biaya tidak langsung biaya promosi dari dalam perusahaan.

2) Learning Cost, yaitu biaya yang dikeluarkan untuk melatih pegawai sampai memiliki kualitas yang diharapkan untuk menduduki jabatan tersebut. Biaya langsung seperti biaya training, orientasi, on the job training. Sementara itu, biaya tidak langsung adalah kerugian yang ditimbulkan dari berkurangnya produktivitas selama pelatihan.

Gambar 2.2. Model untuk Mengukur Biaya Awal SDM

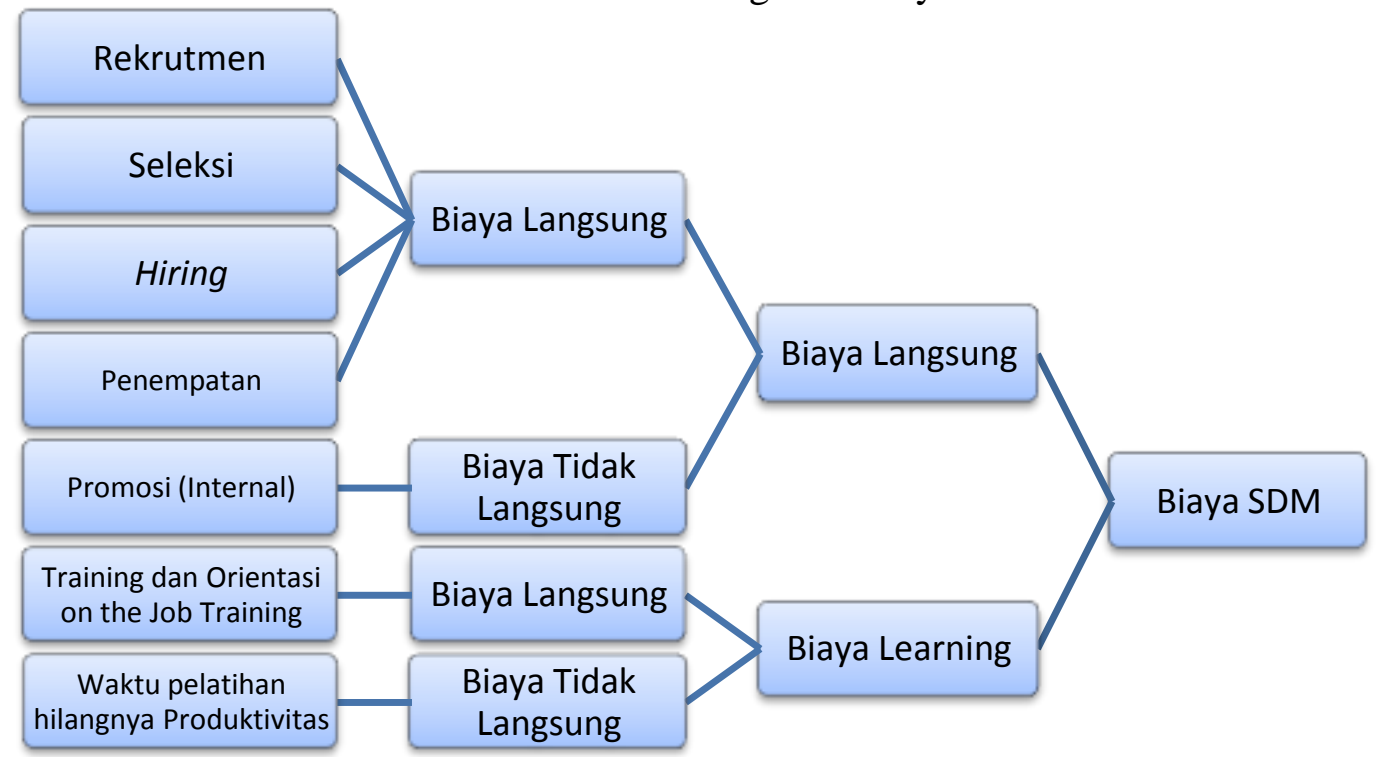

Sumber : Harahap, 2007 
b. The Replacement Cost Model. Model penilaian SDM diukur dengan menaksir besarnya biaya yang akan dikeluarkan untuk mendapatkan pegawai yang sama kualitasnya dengan yang ada sekarang.

c. The Opportunity Cost Model. Model yang dianjurkan oleh Hekimian dan Jones (Belkaoui, 1995), dimana SDM diukur dengan proses penawaran yang bersifat kompetitif yang dilakukan secara intern dengan didasarkan pada konsep opportunity cost. Dalam model ini, investment center manager menawarkan pegawai yang dinilai langka sehingga hanya mereka yang menjadi dasar pengukuran. Dan disinilah letak kelemahan model ini, karena pemilihan atau criteria langka ini dinilai bersifat subjektif dan diskriminatif.

\section{Human Resource Value Model (HRVM)}

Model pengukuran ASDM ini menitikberatkan pada nilai yang dimiliki oleh SDM dan dampaknya terhadap nilai perusahaan. Terdapat dua kelompok besar dalam penilaian ASDM dengan model HRVM.

a. Monetary Model. Model pengukuran ASDM dengan pendekatan monetary model menggunakan nilai satuan uang sebagai ukuran dari SDM yang dimiliki oleh perusahaan. Model-model yang termasuk dalam HRCM dapat dikategorikan sebagai monetary model. Perbedaannya dengan monetary model HRVM adalah titik berat acuan penilaian yang digunakan. Dimana monetary model HRCM menitik beratkan pada biaya yang dikeluarkan perusahaan dalam rangka mendapatkan SDM yang diinginkan. Sedangkan monetary model HRVM lebih menitik beratkan pada nilai yang dimiliki oleh SDM dan dampaknya pada nilai perusahaan. Beberapa monetary model dalam HRVM adalah sebagai berikut.

1) Discounted Wage Flows Method. Nilai SDM dinilai dengan melihat nilai kompensasinya di masa yang akan datang. Rumus perhitungannya adalah sebagai berikut.

Dimana,

$\mathrm{Vr}=$ Nilai sumber daya manusia seseorang pada usia " $r$ "

$\mathrm{I}(\mathrm{t}) \quad=$ Pendapatan yang bersangkutan sampai pension

$\mathrm{r} \quad=$ Tingkat discount khusus untuk seseorang

$\mathrm{T}=$ Umur pension

2) Adjusted Discounted Future Wages Method. Model ini melakukan penyesuaian terhadap nilai kompensasi yang akan diterima pegawai. Discounted dari gaji yang akan datang disesuaikan dengan efficiency factor yang dimaksudkan untuk mengukur efektivitas relatif dari nilai sumber daya manusia sebuah perusahaan. Efficiency factor yang merupakan rasio return on investment (ROI) perusahaan tertentu dibandingkan dengan keseluruhan perusahaan dalam suatu ekonomi pada saat tertentu dihitung dengan rumus sebagai berikut.

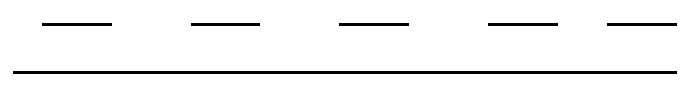

Dimana,

$\mathrm{RF}_{\mathrm{i}} \quad=$ Tingkat laba akuntansi atas asset yang dimiliki perusahaan pada tahun ke-i 

$\mathrm{RE}_{\mathrm{i}}=$ Tingkat laba akuntansi atas asset yang dimiliki keseluruhan perusahaan pada tahun ke-i
$\mathrm{i} \quad=$ Tahun $(0-4)$

Justifikasi rasio ini adalah untuk menunjukkan perbedaan kemampuan perusahaan mendapatkan laba disebabkan oleh perbedaan prestasi SDM yang dimiliki oleh perusahaan

3) Present Monetary Value Method
A = Nilai SDM bagi suatu organisasi formal
$\mathrm{N}=$ Jumlah tenaga kerja yang diperkerjakan organisasi
$\mathrm{t} \quad=$ saat sekarang
$=$ Waktu yang paling sering pegawai meninggalkan organisasi
$\mathrm{G}_{\mathrm{i}}(\mathrm{t}) \quad=$ Nilai jasa yang diberikan seseorang i pada waktu $\mathrm{t}$ kepada organisasi

\section{4) Discounterd Future Value}

Metode ini dikembangkan oleh Brummet, Flamholtz dan Pyle. Mereka menyarankan untuk meramalkan present value dari laba perusahaan pada tingkat rate of return yang normal dan mengalokasikan sebagai dari nilai ekonomis perusahaan sebagai SDM berdasarkan kontribusi relatif dari mereka.

5) Goodwill Methods

Metode ini dikembangkan ole Hermanson. Dia menyarankan diskontokan kelebihan di atas normal expected earning berdasarkan perbandingan perusahaan dalam suatu sector industry dan mengalokasikannya ke aktiva yang belum ada misalnya investasi dalam SDM. Gilbert juga mengusulkan hal yang sama di mana nilai goodwill dialokasikan ke aktiva SDM dan non-SDM berdasarkan rasionya terhadap total aktiva.

6) Economic Value Approach

Metode ini menggunakan penjabaran uang atas expected future services dari services levels dan services group suatu perusahaan, tingkat gaji dan jabatan merupakan service level. Perbedaan tingkat prestasi menggambarkan service greoup.

Kalau $\mathrm{P}(\mathrm{Si})$ merupakan probabilitas seorang individu menduduki tiap keadaan dalam susunan services yang ada maka:

Nilai expected serive output $=$ jumlah produk dari jumlah jasa yang diharapkan diperoleh dari setiap kemungkinan service x expected probabilitas terjadi.

Probabilitas ini bisa probabilitas yang lalu yang diperoleh dari perhitungan aktuaris atau probabilitas berdasarkan pertimbangan pribadi.

b. Non Monetary Model. Saat ini pengukuran SDM yang dimiliki perusahaan masih menggunakan pendekatan nonmoneter. Beberapa metode pengukuran SDM dengan teknik nonmoneter adalah sebagai berikut. (Harahap, 2007).

1) Mendaftar keahlian dan kemampuan seseorang. Metode ini melakukan pembukuan, file atau personal record dari masing-masing pegawai yang berisi tentang keahliannya, pengalamannya, pendidikan, jabatan yang sudah pernah, pengalaman, dan lain-lain. 
2) Pembuatan rating atau ranking atas prestasi seseorang. Dalam menilai prestasi seseorang bisa digunakan rating, ranking, checklist. Hal yand dinilai bisa tingkat pendidikan, pengalaman, dan sebagainya.

3) Penilaian terhadap potensi seseorang. Di sini diukur kemungkinan potensi seseorang jika dipromosikan atau dipindahkan sehingga tahu potensinya jika diberikan tugas baru.

4) Pengukuran sikap. Umumnya disini digunakan untuk mengetahui informasi mengenai tendensi seseorang untuk menyatakan perasaannya tentang suatu objek. Misalnya ditanya sikapnya terhadap pekerjaan, gaji, kualitas, dan lain-lain. Bisa menggunakan skala misalnya; (1) sangat setuju; (2) setuju; (3) tidak tahu; (4) tidak setuju; (5) sangat tidak setuju.

5) Subjectived Expected Utility. Disini digabungkan antara nilai subjektif seseorang dan tingkat keyakinan seseorang akan kemungkinan terjadinya suatu kejadian. Metode psychophysical dikembangkan untuk mengukur utilitas dan probability subjektif dengan menggunakan skala besaran (magnitude) subjektif. Bisa juga melakukan perbandingan pasangan, rating, dan taksiran magnitude.

6) Model Likert-Bowers. Model ini berupaya mengukur variabel yang menentukan efektivitas SDM dalam suatu organisasi. Kuesioner berdasarkan model teori survey organizations didesain untuk mengukur "iklim organisasi". Hasil kuesioner ini dapat dijadikan sebagai dasar dalam membantu mengukur nilai sumber daya manusia dengan menggambarkan persepsi karyawan tentang atmosfir kerja di suatu perusahaan. Kemudian digabungkan dengan pendekatan perilaku dan ekonomi maka lahirlah nilai SDM.

7) Penilaian kinerja (performance appraisal). Pada dasarnya merupakan faktor kunci guna mengembangkan suatu organisasi secara efektif dan efisien, karena adanya kebijakan atau program yang lebih baik atau sumber daya manusia yang ada dalam organisasi. Penilaian kinerja individu sangat bermanfaat bagi dinamika pertumbuhan organisasi secara keseluruhan, melalui penilaian tersebut maka dapat diketahui kondisi sebenarnya tentang bagaimana kinerja karyawan. Dessler (2009) mendefinisikan penilaian kinerja sebagai evalusi kinerja karyawan saat ini atau dimasa lalu relatif terhadap standar prestasinya. Bernardin dan Russel (Gomes, 2003) " A way of measuring the contribution of individuals to their organization". Penilaian kinerja adalah cara mengukur kontribusi individu (karyawan) kepada organisasi tempat mereka bekerja. Model penilaian kinerja yang dicontohkan oleh Gary Dessler (2009) meliputi indikator sebagai berikut.

a) Kualitas kerja adalah akurasi, ketelitian, dan bisa diterima atas pekerjaan yang dilakukan.

b) Produktivitas adalah kuantitas dan efisiensi kerja yang dihasilkan dalam periode waktu tertentu.

c) Pengetahuan pekerjaan adalah keterampilan dan informasi praktis/teknis yang digunakan pada pekerjaan.

d) Bisa diandalkan adalah sejauh mana seorang karyawan bisa diandalkan atas penyelesaian dan tindak lanjut tugas.

e) Kehadiran adalah sejauh mana karyawan tepat waktu, mengamati periode istirahat/makan yang ditentukan dan catatan kehadiran secara keseluruhan.

f) Kemandirian adalah sejauh mana pekerjaan yang dilakukan dengan atau tanpa pengawasan. 


\section{Kendala dalam Mengaplikasikan ASDM}

ASDM merupakan salah satu bentuk perkembangan dalam ilmu Akuntansi. Hanya saja, sampai saat ini belum adanya kesepakatan dalam menerapkan SDM sebagai Asset yang dimiliki oleh perusahaan. Penelitian yang dilakukan oleh Rispantyo menyimpulkan, belum adanya kesepakatan tersebut dikarenakan untuk dapat dikategorikan sebagai aktiva, maka sumberdaya manusia harus memenuhi syarat: difinition, measurement, relevan dan reliability. Dari beberapa syarat tersebut, yang menjadi permasalahan utama untuk dapat menerapkan akuntansi sumberdaya manusia adalah measurement.

Sementara itu, Suwarto (2006) dalam Ayu dan Didied mengemukakan, kendala atau masalah yang mungkin ditemui dalam penerapan ASDM dapat berupa masalah teknis dan masalah konsep. Masalah teknis, berupa ASDM berdasar nilai boleh dikatakan lebih berpotensi daripada masalah konsep karena aspek teknis penilaian ASDM dapat berdasarkan penilaian para ahli dari luar profesi akuntan, seperti Psikolog, Psikometrisian, dan lain sebagainya.

Sebagai suatu konsep ASDM belum dapat diterima sebagai suatu GAAP (Generally Accepted Accounting Principles) atau prinsip-prinsip yang berlaku umum, hal ini disebabkan karena adanya syarat pengukuran suatu item tertentu sebagai suatu asset yang diatur dalam FASB no.5 (Tunggal, 2004) yaitu: (1) Measurement (dapat diukur) dan (2) Relevance dan reliability.

Gambling (1976) dalam Ayu dan Didied berargumentasi bahwa tidak mungkin untuk memasukkan sumber daya manusia ke dalam neraca seperti gedung dan bangunan pabrik. Ia juga berpendapat bahwa kapitalisasi atas biaya rekrut dan pelatihan termasuk dalam problema pengalokasian overhead.

Mee (1982) dalam Ayu dan Didied juga berargumentasi bahwa human asset tidak dapat diuraikan dari elemen-elemen yang lain dari suatu organisasi yaitu pegawai berinteraksi dan mencapai efektivitas. Ia juga menambahkan bahwa suatu organisasi tidak dapat mengontrol manusia sama halnya dengan mengontrol asset fisik.

\section{PENUTUP}

ASDM merupakan salah satu perkembangan dari ilmu akuntansi. Pada dasarnya ASDM adalah pengakuan dan pengukuran SDM yang dimiliki oleh suatu perusahaan sebagai asset. Sejak dikeluarkan gagasan untuk mengakui SDM sebagai asset yang dimiliki oleh perusahaan, telah banyak model pendekatan yang diajukan untuk pengakuan dan pengukuran SDM sebagai asset perusahaan. Hanya saja, sampai saat ini belum ada kesepakatan bersama mengenai bagaimana pengakuan dan pengukuran SDM ke dalam laporan keuangan.

Belum adanya kesepakatan bersama mengenai pengukuran SDM merupakan masalah utama dalam mengaplikasikan ASDM dalam pelaporan keuangan. Banyaknya jenis perusahaan, serta cara pandang perusahaan dalam menilai SDM yang dimilikinya menyebabkan sulitnya tercapai kesepakatan bersama dalam mengaplikasikan pengukuran dari ASDM. Selain pengukuran, masalah lain dari mengaplikasikan SDM dalam laporan keuangan adalah suatu organisasi tidak dapat mengendalikan secara penuh atas manusia. Berbeda halnya dengan asset fisik lainnya, manusia adalah suatu individu yang memiliki kehendak dan dapat membuat keputusan sendiri. Faktor psikologi dari SDM dapat menjadi pengaruh yang sangat berarti bagi kinerja individu tersebut dalam organisasi. Seorang pegawai bisa saja mengundurkan diri karena ketidakpuasan kerja di perusahaan.

Berdasarkan pada hasil riset ini, maka penulis menyarankan untuk adanya riset lanjutan mengenai ASDM. Upaya yang dapat dilakukan untuk memudahkan pengaplikasian ASDM adalah dengan menggolongkan terlebih dahulu. Hal ini dikarenakan, masing-masing jenis perusahaan memiliki cara pandang tersendiri atas SDM yang dimilikinya. Menurut penulis, suatu perusahaan yang sangat mengandalkan pengembangan kemampuan SDM-nya 
(intellectual capital) adalah perusahaan yang lebih cocok untuk dijadikan objek penelitian dalam menerapkan ASDM. Hal ini didasarkan atas materialitasnya biaya yang dialokasikan oleh perusahaan untuk menjaga kualitas intellectual capital-nya.

\section{DAFTAR PUSTAKA}

Ayu, Didied. Analisis Penerapan Akuntansi Sumber Daya Manusia terhadap Perbandingan Kinerja Laporan Keuangan pada PT. BPRS Mitra Harmoni Malang. Jurnal Universitas Brawijaya, Malang.

Belkaoui. 1995. Akuntansi Sumber Daya Manusia, edisi Bahasa Indonesia. PT. Prehallindo, Jakarta.

Brummet, R. Lee. 1995. Human Resource Accounting: Modern Accounting. Alih Bahasa Tim penerjemah CV. Alfa Beta, Bandung.

Dessler Gary. 2009. Manajemen Sumber Daya Manusia. Index, Jakarta

Faustino Cardoso Gomes. 2003. Manajemen Sumber Daya Manusia. Andi Offset, Yogyakarta.

Harahap. 2007. Teori Akuntansi. PT. Raja Grafindo Persada, Jakarta.

Lako Andreas. 1995. Akuntansi Sumber Daya Manusia: Pengakuan dan Pelaporan Sumber Daya Manusia Sebagai Asset Organisasi, UPP - AMP YKPN, Yogakarta.

Mirza Abbas, Holt Graham. 2011. Practical Implementation Guide and Workbook for IFRS, third edition. Wiley. United States of America

Nicoline. 2010. Akuntansi Sumber Daya Manusia: Pengukuran dan Pelaporan. Vol.4 No.2. Maluku.

Rispantyo. Akuntansi Sumberdaya Manusia: Antara Hidup dan Mati. Jurnal Fakultas Ekonomi Universitas Slamet Riyadi, Surakarta.

Tunggal. 1995. Akuntansi Sumber Daya Manusia. Rineka Cipta, Jakarta. 